\title{
Rhinological factors predisposing to headaches: our experience
}

\author{
Dmitry Tretiakow 모, Andrzej Skorek
}

Department of Otolaryngology, Medical University of Gdańsk, Poland

\begin{abstract}
Background: This study aimed to present the correlation between headaches and anatomical changes within the nasal cavity and paranasal sinuses. Material and methods: This study includes a literature search and our observations of 24 patients regarding the correlation of headaches with the nasal cavity and paranasal sinus anatomy. Results: According to the literature, about $12 \%$ of the population suffer from chronic/recurrent headaches. In about $60 \%$ of patients, the headache was accompanied by different types of the anatomical structure of the nasal cavity and paranasal sinuses, which may predispose to frequent recurrence or poor control of pain. We observed 2 groups of patients. Group I consisted of 18 patients, who in according to the according to ICHD-3 classification were diagnosed with a headache or facial pain attributed to disorder of the head or neck. Group II included 6 patients with a non-diagnosed recurrent headache, who after septoplasty reported either complete headache resolution or a significantly reduced frequency of headache attacks and duration. Statistically significant differences in the surgical treatment outcomes between patients before and after therapy were observed ( $p$ $=0,00001)$. Conclusion: Several anatomical changes can predispose or cause recurrent headaches. In most cases, they require surgical intervention.
\end{abstract}

Keywords: nasal septum deviation - Haller cells $\cdot$ concha bullosa $\cdot$ nasal turbinate hypertrophy $\cdot$ headaches $\cdot$ nasal sinus $\cdot$ treatment.

\section{Citation}

Tretiakow D, Skorek A. Rhinological factors predisposing to headaches: our experience. Eur J Transl Clin Med. 2021;4(1):50-56.

DOI: $10.31373 /$ ejtcm/134449

\section{Introduction}

Recurrent headache often causes the patient to consult an otolaryngologist. In addition to headache, these patients have various types and degrees of discomfort in the nose and the paranasal sinuses (e.g. feeling of blockage/pressure in the nasal cavity, impaired nasal patency, chronic runny nose) [1-3]. Patients describe the headache as a pain in the paranasal sinuses region (frontal, maxillary) or the face, pain in the maxilla or jaw,

Corresponding author:

Dmitry Tretiakow, Department of Otolaryngology, Medical University of Gdańsk, Poland

e-mail: d.tretiakow@gmail.com

Funding: No external funds

Available online: www.ejtcm.gumed.edu.pl

Copyright ${ }^{\circledR}$ Medical University of Gdańsk

This is Open Access article distributed under the terms of the Creative Commons Attribution-ShareAlike 4.0 International.

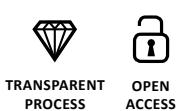


pain in the temporal area or auricle. However, when these symptoms are accompanied by gastrointestinal complaints or sensory hypersensitivity (to light or noise), patients may suffer from primary headaches such as migraine and trigeminal neuralgia. According to the International Classification of Headache Disorders 3rd edition (ICHD-3), this type of headache is classified as headache or facial pain attributed to disorder of the cranium, neck, eyes, ears, nose, sinuses, teeth, mouth, or other facial or cervical structure (part 11) [4].

In this review, we would like to discuss the otolaryngologist's role in identifying the causes and the treatment of recurrent headaches. We also reviewed the latest evidence-based diagnostic criteria and treatment methods, both new and traditional, concerning otolaryngological practice.

\section{Material and methods}

The first part of our work was to find current literature about chronic/recurrent headaches. Changes in the anatomy of the nasal cavity and paranasal sinuses may be the mechanism that induces them. We used the MEDLINE, PubMed and Scopus databases to search for English-language literature published in the years 20002020. The search keywords were "migraine," "headache," "nasal septum deviation," "concha bullosa," "septal bullosa," "Haller cell" and synonyms of these words.

The second part of the study presents our observations in the period 2014-2020. We studied the correlation between headache occurence and anatomical changes in the nasal cavity and paranasal sinuses. We analyzed the medical data of 18 patients with chronic headaches (Group I). A neurologist diagnosed these headaches as a headache or facial pain attributed to a disorder of the cranium, neck, eyes, ears, nose, sinuses, teeth, mouth, or other facial or cervical structure (ICHD-3, part 11). The second group (Group II) consisted of patients $(n=6)$ with impaired nasal patency who qualified for nasal septum plastic surgery. In the postoperative period, these patients reported a noticeable reduction in the frequency of headaches. However, in the pre-operative period during the nasal septum surgery qualification, they did not mention these complaints.

To assess the headache severity level, we used the generally accepted visual analogue scale (VAS) [5]. In patients from group II, pre-surgery pain assessment was performed retrospectively based on the patient's information after surgery. According to VAS before and after treatment, numerical characteristics and percentage rates were determined to evaluate patients' headache severity level, both in groups I and II (Table 1). The significance of differences between the treatment outcomes was determined using the Mann-Whitney $U$ test.
Table 1. Symptoms of migraine headaches caused by anatomical variations of the nasal cavity and paranasal sinuses

\begin{tabular}{|c|c|c|c|c|}
\hline $\begin{array}{l}\text { Group } \\
(n)\end{array}$ & $\begin{array}{l}\text { Sex } \\
(n)\end{array}$ & $\begin{array}{l}\text { VAS } \\
\text { pre-op } \\
\text { mean } \\
\text { (SD) }\end{array}$ & $\begin{array}{c}\text { VAS } \\
1 \text { month } \\
\text { post-op } \\
\text { mean (SD) }\end{array}$ & $\begin{array}{c}\text { VAS } \\
6 \text { monthes } \\
\text { post-op } \\
\text { mean (SD) }\end{array}$ \\
\hline $\mathbf{I}$ & $\mathrm{F}$ & 7 & 6 & 5 \\
\hline I & $\mathrm{F}$ & 8 & 7 & 5 \\
\hline I & $\mathrm{F}$ & 8 & 7 & 5 \\
\hline I & $F$ & 7 & 7 & 4 \\
\hline I & $F$ & 8 & 7 & 6 \\
\hline I & $\mathrm{F}$ & 8 & 7 & 6 \\
\hline $\mathbf{I}$ & $F$ & 8 & 7 & 5 \\
\hline $\mathbf{I}$ & $F$ & 7 & 7 & 4 \\
\hline I & $F$ & 7 & 4 & 0 \\
\hline $\mathbf{I}$ & $F$ & 8 & 7 & 5 \\
\hline I & $F$ & 8 & 7 & 5 \\
\hline $\mathbf{I}$ & $F$ & 8 & 8 & 5 \\
\hline I & $F$ & 8 & 7 & 5 \\
\hline I & $F$ & 8 & 7 & 6 \\
\hline I & $F$ & 7 & 6 & 4 \\
\hline I & $M$ & 7 & 6 & 0 \\
\hline I & $M$ & 8 & 6 & 4 \\
\hline I & $M$ & 8 & 7 & 3 \\
\hline II & $\mathrm{F}$ & 4 & 3 & 2 \\
\hline II & $F$ & 4 & 3 & 2 \\
\hline II & $F$ & 4 & 3 & 2 \\
\hline II & $\mathrm{F}$ & 4 & 3 & 2 \\
\hline II & $M$ & 4 & 3 & 0 \\
\hline II & $M$ & 5 & 4 & 2 \\
\hline
\end{tabular}

$\mathrm{F}$ - female, $\mathrm{M}$ - male, VAS - visual analogue scale 


\section{Results}

\section{Review of literature}

Seventy-five full-text articles were found and analyzed. According to the literature, about $12 \%$ of the population, including $18 \%$ women and $6 \%$ men, suffer from chronic headaches [6-8]. In a large proportion of them (about 60\%), a headache was accompanied by different types of the anatomical structure of the nasal cavity and the paranasal sinuses, which may predispose to frequent recurrences or poor pain control [2, 9-10]. Understanding this relationship and using various therapeutic methods to remove these anomalies is very rewarding for both the patient and the surgeon. It is crucial to obtain detailed history about headaches, to ask the patients the right questions before the planned surgery on the nose and paranasal sinuses. Many patients did not report this because they do not see the relationship between the nasal sinus problem and headaches.

The correct diagnosis of chronic/recurrent headaches is essential. The differential diagnosis of headache should include meningitis, and cerebral meningitis, vascular disorders of the central nervous system, proliferative disorders (primary and secondary) and inflammatory diseases of the head and neck. The consequences of an incorrect diagnosis can be catastrophic. On the other hand, some patients may experience headaches associated with using (often misusing) medications (rebound headaches). In this group of patients, surgical treatment of concomitant rhinological changes did not resolve or reduce the level of complaints [3, 11-12]. The ad-hoc pharmacological control of chronic headaches usually is sufficient. The lack of complementary/adjuvant rhinological therapy may lead to frequent recurrences of the headache after discontinuing the medication [13-14]. Guyuron et al showed that the operation gave permanent results with limited or often discontinuation therapy [2].

\section{Symptoms}

In patients with chronic headaches and predisposing factors in the nasal cavity and sinuses, the pain is often induced by a change in weather and usually begins behind the eyes $[11,15]$. The patient often reports waking at night up or in the morning with a headache. These symptoms may be accompanied by a runny nose or stuffy nose, usually one-sided. The recurrent headache can also be associated with menstruation because the nasal turbinates' volume depends on estrogen concentration [11]. Pain is usually described as "exploding" and may begin with deeper head structures, later radiating to the periphery (Table 2) [9-11].
Table 2. Patient demographic characteristics and results of surgical treatment

- The pain starts behind the eye.

- Weather changes may cause migraine headaches.

- The patient wakes up in the middle of the night or in the morning because of a headache.

- Rhinitis/nasal obstruction on the affected side.

- The pain is described as exploding.

The otolaryngological examination of the nasal cavity most often reveals a " $C$ " shaped nasal septum deviation. This particular anatomy means that the nasal septum is in direct contact with the lateral wall of the nasal cavity or nasal turbinate, thus causing mucosal edema (or hypertrophy) and chronic headaches. These patients often have a reduction in headaches after using nasal decongestants (e.g. xylometazoline, oxymetazoline, phenylephrine, pseudoephedrine) $[3,8,16]$. Other anatomical factors predisposing to migraine headaches can be detected only in imaging.

\section{Imaging}

The best imaging technique for identifying anatomical changes is a non-contrast computer tomography (CT) scan (Fig. 1). Particular attention should be paid to the nasal septum, particularly its bony segment (often invisible on rhinoscopic examination). Usually, these images show a significant deflection of the septum (or spur) penetrating the lower and/or middle nasal turbinate (Fig. 2B) and even reaching the nasal cavity's lateral wall. CT scans may also reveal concha bullosa (Fig. 2A), paradoxical curling of the middle nasal turbinate (Fig. 3A), septa bullosa (Fig. $3 B)$, or Haller cell (Fig. 3C) [3, 10, 17].

\section{Treatment}

Patients with nasal and nasal sinus anomalies who were examined by a neurologist are good candidates for nasal and sinus surgery. A neurological examination revealed at least two headaches per month, which are so severe that they require prescription drugs and significantly change the patient's quality of life $[9,17-18]$. According to the literature, using functional sinus endoscopic surgery (FESS) in the treatment 

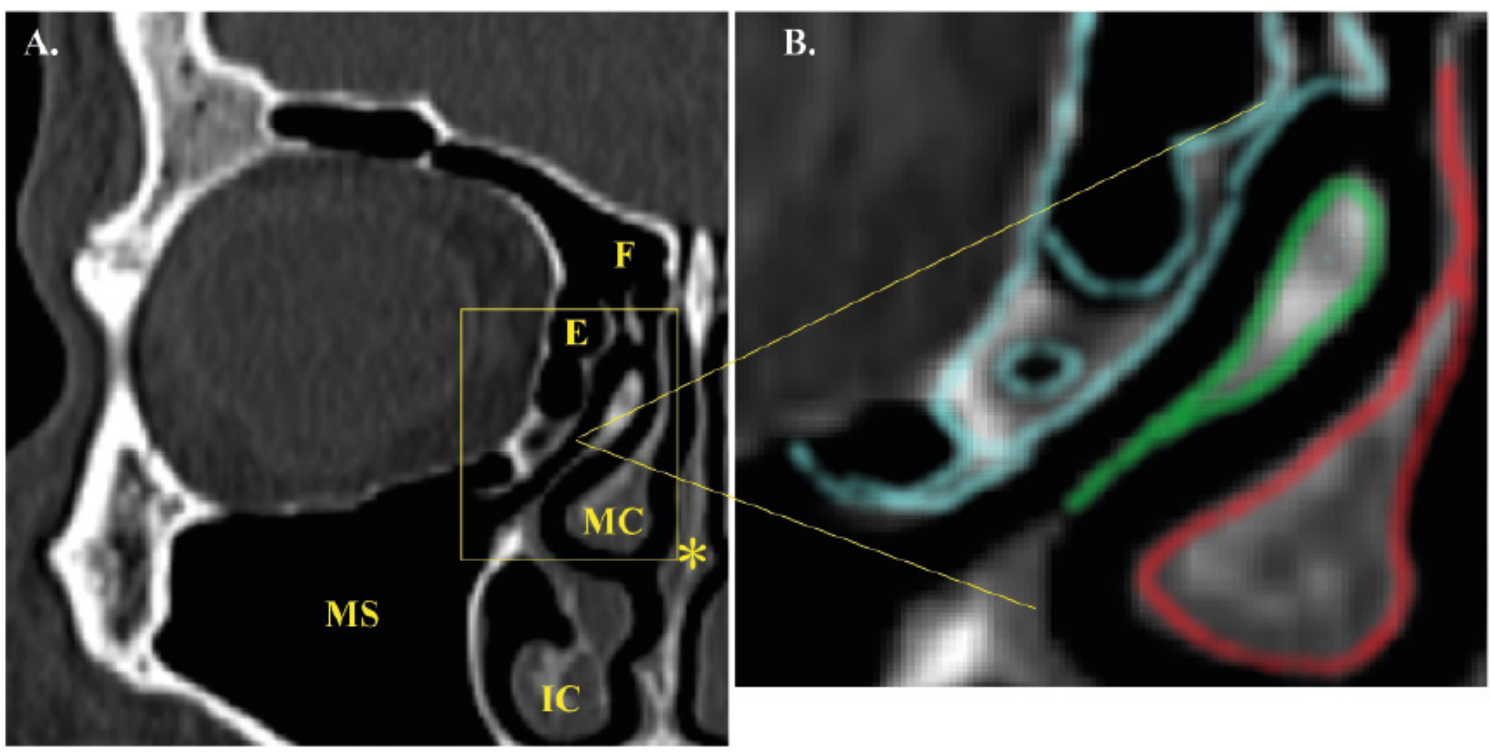

Figure 1. Computed tomography. (A) Image of normal anatomical structures of the nose and paranasal sinuses. The nasal septum is straight. The ostiomeatal complex and the paranasal sinuses are patent. Normal pneumatization of the paranasal sinuses. Nasal turbinates are not enlarged. (B) Image of a normal right ostiomeatal complex (blue - ethmoid sinus cells; green - uncinate process of ethmoid bone; red - middle nasal turbinate). MS - maxillary sinus; E - ethmoid sinus; F - frontal sinus; MC - middle concha; IC - inferior concha; ${ }^{*}$ - nasal septum.

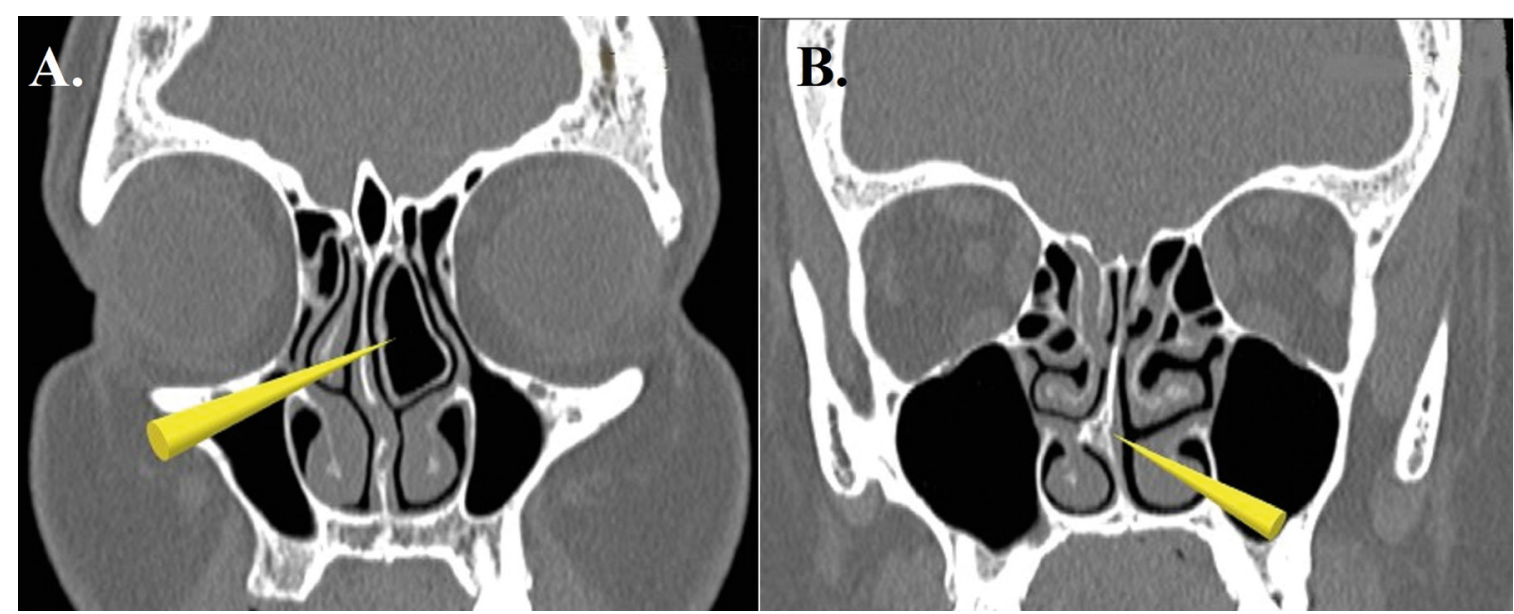

Figure 2. Computed tomography. (A) Concha bullosa - the air cell forms the shaft of the nasal turbinate. (B) The nasal septum spike touches the medial surface of the lower right nasal turbinate.
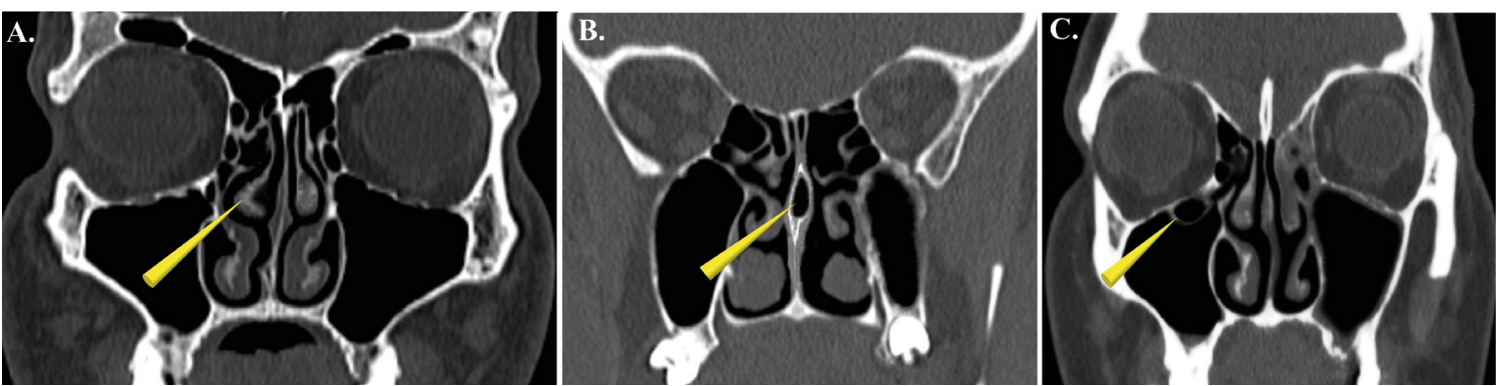

Figure 3. Computed tomography. (A) The hook-shaped middle nasal turbinate on the right side and (B) the septa bullosa. The nasal septum contains an air cell in the posterior $1 / 3$ of its length. (C) The right maxillary sinus contains a Haller cell located near the lower-medial orbital wall. 
of patients initially qualified for conchoplasty and/or septoplasty to eliminate migraine-related factors can make surgery results more satisfactory. Under these conditions, compliance with the criterion of the minimum frequency of headaches is not critical $[2,17]$.

Patients can still use the medication if they still have headache recurrence (botulinum toxin $A$ injection into masseter muscle) [19]. The presence of these symptoms in the early postoperative period, in which we often observe edematous changes in the nose, should not worry either the patient or the surgeon. Headache regression or reduction may take up to 3-6 months. However, many patients experience positive effects soon after the surgery and consider this surgery very beneficial $[2,12,14,18,20]$.

\section{Our experience}

In 2014-2020, we observed 18 patients with a chronic headache diagnosed by a neurologist (Group I) (Table 3). Before surgery in this group, the headache attack duration was 4-48 hours (mean 14 hours). Whereas after septoplasty, these patients reported either complete resolution of headaches or a significant reduction of the frequency and/or duration of the headache attacks.
In group I before nasal septum surgery, 4 patients (22\%) suffered from recurrent headache experienced $\geq 4$ strong attacks per month, 8 (44\%) had 1-4 strong attacks/month, and 6 (34\%) had a $\leq 1$ severe attack in a month. In the postoperative period, the frequency of attacks decreased: 2 patients (11\%) suffering from the recurrent headache had $\geq 4$ strong attacks per month, 5 (27\%) had 1-4 strong attacks/month, and 9 (51\%) had $a \leq 1$ strong attack per month. In 2 patients (11\%), recurrence of headaches resolved entirely (Table 4).

We also observed a group of patients $(n=6)$ with impaired nasal patency (Group II) who reported a noticeable reduction in the frequency of the headache attack in the postoperative period. Although in the pre-operative period (during the qualification for surgery) they did not report a recurrent headache because they thought it had no cause-and-effect relationship (Table 2).

The probability value ( $p$-value) analysis was made only for the group of women in Group I ( $p<0,00001)$ because it is the only group in our patient sample that was large enough to statistically analyze their results (Table 2).

\section{Discussion}

The available literature contains information that confirms the correlation between anatomical changes

Table 3. The incidence of migraine headaches in patients in Group I applied before and after surgery

\begin{tabular}{|c|c|c|c|c|c|c|c|c|}
\hline Group (n) & $\operatorname{Sex}(n)$ & $\begin{array}{l}\text { Age } \\
\text { Min- } \\
\text {-Max } \\
\text { (mean; } \\
\text { SD) }\end{array}$ & $\begin{array}{l}\text { Partial } \\
\text { impro- } \\
\text { vement }\end{array}$ & $\begin{array}{l}\text { Comple- } \\
\text { te reso- } \\
\text { lution }\end{array}$ & $\begin{array}{c}\text { VAS } \\
\text { pre-op } \\
\text { mean (SD) }\end{array}$ & $\begin{array}{c}\text { VAS } \\
1 \text { month } \\
\text { post-op } \\
\text { mean } \\
\text { (SD) }\end{array}$ & $\begin{array}{c}\text { VAS } \\
6 \text { months } \\
\text { post-op } \\
\text { mean } \\
\text { (SD) }\end{array}$ & $\begin{array}{l}P< \\
0,05\end{array}$ \\
\hline \multirow[t]{2}{*}{ I (18) } & $F(15)$ & $\begin{array}{c}24-52 \\
(37,3 ; \\
8,8)\end{array}$ & 14 & 1 & $7,7(0,85)$ & $6,75(0,86)$ & $4,7(1,4)$ & $\begin{array}{c}p< \\
0,00001\end{array}$ \\
\hline & $M(3)$ & $\begin{array}{c}27-39 \\
(33 ; \\
8,5)\end{array}$ & 2 & 1 & $7,6(0,78)$ & $6,5(0,7)$ & $2,3(2,1)$ & $\begin{array}{l}\text { un- } \\
\text { defi- } \\
\text { ned }\end{array}$ \\
\hline \multirow[t]{2}{*}{ II (6) } & $F(4)$ & $\begin{array}{c}31-45 \\
(37,3 ; \\
6,1)\end{array}$ & 4 & 0 & $4,0(0,8)$ & $3,0(0,8)$ & $2,0(0,8)$ & $\begin{array}{l}\text { un- } \\
\text { defi- } \\
\text { ned }\end{array}$ \\
\hline & $M(2)$ & $\begin{array}{c}29-34 \\
(31,5 \\
3,5)\end{array}$ & 1 & 1 & $4,5(0,7)$ & $3,5(0,7)$ & $1,0(1,4)$ & $\begin{array}{l}\text { un- } \\
\text { defi- } \\
\text { ned }\end{array}$ \\
\hline
\end{tabular}

$\mathrm{F}$ - female, $\mathrm{M}$ - male, VAS - visual analogue scale 
Table 4. The incidence of migraine headaches in patients in Group I applied before and after surgery

\begin{tabular}{|c|c|c|c|c|}
\hline Group $(\mathbf{n})$ & $\begin{array}{c}\geq 4 \text { severe } \\
\text { pain attacks } \\
\text { in a month }\end{array}$ & $\begin{array}{c}1-4 \text { severe } \\
\text { pain attacks in } \\
\text { a month }\end{array}$ & $\begin{array}{c}\leq 1 \text { severe } \\
\text { pain attacks } \\
\text { in a month }\end{array}$ & No complaints \\
\hline $\begin{array}{c}\text { Pre-operative } \\
\text { period }\end{array}$ & $22 \%(n=4)$ & $44 \%(n=8)$ & $34 \%(n=6)$ & 0 \\
\hline $\begin{array}{c}\text { Post-operative } \\
\text { period }\end{array}$ & $11 \%(n=2)$ & $27 \%(n=5)$ & $51 \%(n=9)$ & $11 \%(n=2)$ \\
\hline
\end{tabular}

in the nasal cavity and the frequency of headache attacks $[1,11,18]$. The groups of patients in whom surgery of the nasal septum, concha bullosa, septa bullosa, or Haller's cells led to decreased headaches, and the frequency of its attacks were described. Diagnosis and differentiation of headaches are an indispensable part of treating a patient with chronic headaches. Physicians of different specialties should participate in this process because a multi-disciplinary treatment approach can lead to the positive outcomes. CT of the nose and paranasal sinuses is very helpful and is the gold standard in detecting anatomical factors predisposing to a headache's intensification.

Our study provided similar results and indicated improvement in patients' quality of life after nasal surgery. According to our observation, headaches may appear/ worse in patients with impaired nasal patency. Often, patients do not report these complaints during the qualification for surgery of the nose and paranasal sinuses because they are not aware their headache and a nasal or nasal sinus problem are related. Therefore, before surgery it seems crucial to ask these patients questions about headaches. Analyzing the treatment results of our patients in groups I and II, we observed that the female patients with nasal septal deformation reported a significant improvement there headache condition after septoplasty. Our study is limited because it covered a small group of patients with a chronic headache associated with the nasal septum deformation. Furthermore, our study did not include patients with the concha bullosa, the septa bullosa, and Haller cells.

\section{Conclusions}

Approximately $60 \%$ of the recurrent headaches were accompanied by different types of the anatomical structure of the nasal cavity and paranasal sinuses, which may predispose to frequent recurrence or poor control of pain The most common pathology diagno- sed in the nasal cavity predisposing to a recurrence of a headache is a nasal septum deformation and the concha bullosa. The nasal septum most often has contact with the nasal turbinate (middle, lower) or even the nasal cavity's lateral wall. A chronic headache that originates in the nasal cavity and sinuses (usually located behind the eyes) is sensitive to hormonal changes in the body and fluctuations in atmospheric pressure. It occurs more often in the morning and/or can wake up the patient at night. It is often associated with a running nose and has an exploding nature. CT images allow us to visualize the nasal septum's point of contact with the nasal cavity's lateral wall, recognize the concha bullosa, the septa bullosa, and Haller cells in the maxillary sinus. CT scan allows visualizing various stages of the inflammation and the cancerous lesions within the paranasal sinuses. Surgical treatment includes septoplasty, conchoplasty, decompression of the concha bullosa, the septa bullosa, or Haller cells.

\section{Declarations}

Conflicts of interest: The authors certify no conflict of interest with any financial organization regarding the material discussed in this manuscript.

Funding: This research did not require funding.

Ethical approval: Ethical approval was not necessary for the preparation of this article.

\section{Authors' contributions:}

Dmitry Tretiakow: literature search, study design, data analysis, data interpretation, writing, critically revised manuscript, gave final approval.

Andrzej Skorek: contributed to the study concept, design and data acquisition, critically revised manuscript, gave final approval. 


\section{References}

1. May A, Schulte LH. Chronic migraine: risk factors, mechanisms and treatment. Nat Rev Neurol [Internet]. 2016 Aug 8;12(8):455-64. Available from: https://doi.org/10.1038/nrneurol.2016.93

2. Guyuron B, Kriegler JS, Davis J, Amini SB. Five-Year Outcome of Surgical Treatment of Migraine Headaches. Plast Reconstr Surg [Internet]. 2011 Feb;127(2):603-8. Available from: https://doi.org/10.1097/PRS.0b013e3181fed456

3. Charles A. Migraine. Solomon CG, editor. N Engl J Med [Internet]. 2017 Aug 10;377(6):553-61. Available from: https:// doi.org/10.1056/NEJMcp1605502

4. Olesen J. From ICHD-3 beta to ICHD-3. Cephalalgia [Internet]. 2016 Apr 10;36(5):401-2. Available from: https://doi. org/10.1177/0333102415596446

5. Tretiakow D, Skorek A. Scientific tools for collecting and analysing medical data in rhinology. Pol Przegląd Otorynolaryngologiczny [Internet]. 2020 Mar 3;9(1):1-5. Available from: https://doi.org/10.5604/01.3001.0013.9128

6. 61st Annual Scientific Meeting American Headache Society ${ }^{\circledR}$ July 11-14 2019 Pennsylvania Convention Center Philadelphia, PA. Headache J Head Face Pain [Internet]. 2019 Jun;59:1-208. Available from: https://doi.org/10.1111/head.13549

7. Faber C, Garcia RM, Davis J, Guyuron B. A Socioeconomic Analysis of Surgical Treatment of Migraine Headaches. Plast Reconstr Surg [Internet]. 2012 Apr;129(4):871-7. Available from: https://doi.org/10.1097/PRS.0b013e318244217a

8. Schwedt TJ, Digre K, Tepper SJ, Spare NM, Ailani J, Birlea M, et al. The American Registry for Migraine Research: Research Methods and Baseline Data for an Initial Patient Cohort. Headache J Head Face Pain [Internet]. 2020 Feb 22;60(2):33747. Available from: https://doi.org/10.1111/head.13688

9. Lipton RB, Bigal ME. Migraine: Epidemiology, Impact, and Risk Factors for Progression. Headache J Head Face Pain [Internet]. 2005 Apr;45(s1):S3-13. Available from: https://doi.org/10.1111/i.1526-4610.2005.4501001.x

10. Burstein R, Noseda R, Borsook D. Migraine: Multiple Processes, Complex Pathophysiology. J Neurosci [Internet]. 2015 Apr 29;35(17):6619-29. Available from: https://doi.org/10.1523/JNEUROSCI.0373-15.2015

11. Welch E. Headache. Nurs Stand [Internet]. 2005 Feb 23;19(24):45-52. Available from: https://doi.org/10.7748/ ns2005.02.19.24.45.c3811

12. Kurlander DE, Punjabi A, Liu MT, Sattar A, Guyuron B. In-Depth Review of Symptoms, Triggers, and Treatment of Temporal Migraine Headaches (Site II). Plast Reconstr Surg [Internet]. 2014 Apr;133(4):897-903. Available from: https://doi. org/10.1097/PRS.0000000000000045

13. Marmura MJ, Silberstein SD, Schwedt TJ. The Acute Treatment of Migraine in Adults: The American Headache Society Evidence Assessment of Migraine Pharmacotherapies. Headache J Head Face Pain [Internet]. 2015 Jan;55(1):3-20. Available from: https://doi.org/10.1111/head.12499

14. Guyuron B, Reed D, Kriegler JS, Davis J, Pashmini N, Amini S. A Placebo-Controlled Surgical Trial of the Treatment of Migraine Headaches. Plast Reconstr Surg [Internet]. 2009 Aug;124(2):461-8. Available from: https://doi.org/10.1097/ PRS.0b013e3181adcf6a

15. Bugten V, Nilsen AH, Thorstensen WM, Moxness MHS, Amundsen MF, Nordgård S. Quality of life and symptoms before and after nasal septoplasty compared with healthy individuals. BMC Ear, Nose Throat Disord [Internet]. 2016;16(1):13. Available from: https://doi.org/10.1186/s12901-016-0031-7

16. Ceriani CEJ, Wilhour DA, Silberstein SD. Novel Medications for the Treatment of Migraine. Headache J Head Face Pain [Internet]. 2019 Oct 26;59(9):1597-608. Available from: https://doi.org/10.1111/head.13661

17. Larson K, Lee M, Davis J, Guyuron B. Factors Contributing to Migraine Headache Surgery Failure and Success. Plast Reconstr Surg [Internet]. 2011 Nov;128(5):1069-75. Available from: https://doi.org/10.1097/PRS.0b013e31822b61a1

18. Gfrerer L, Guyuron B. Surgical treatment of migraine headaches. Acta Neurol Belg [Internet]. 2017 Mar 24;117(1):27-32. Available from: https://doi.org/10.1007/s13760-016-0731-1

19. Hansson-Hedblom A, Axelsson I, Jacobson L, Tedroff J, Borgström F. Economic consequences of migraine in Sweden and implications for the cost-effectiveness of onabotulinumtoxinA (Botox) for chronic migraine in Sweden and Norway. J Headache Pain [Internet]. 2020 Dec 12;21(1):99. Available from: https://doi.org/10.1186/s10194-020-01162-x

20. Kung TA, Guyuron B, Cederna PS. Migraine Surgery: A Plastic Surgery Solution for Refractory Migraine Headache. Plast Reconstr Surg [Internet]. 2011 Jan;127(1):181-9. Available from: https://doi.org/10.1097/PRS.0b013e3181f95a01 